\title{
PENÉLOPE E A ARTE DA INDECISÃO NA ODISSEIA
}

André Malta*

Universidade de São Paulo

\begin{abstract}
The aim of this paper is to discuss some passages of the Odyssey that are important to the characterization of Penelope as "undecided" - at the same time someone who is victim and in the control of her destiny. I'll try to show (as others did before) that this indecision, far from making Penelope an incongruous character, is responsible for her complexity and has a decisive role in drawing the narrative to an end.
\end{abstract}

KEYWORDS: Homer; Odyssey; Penelope; woman; indecision.

\begin{abstract}
OP
m estudioso norte-americano resumiu assim a participação de Penélope na Odisseia: "Homero define Penélope para nós numa série de pares repetidamente enfatizados: suas principais qualidades são a beleza e a prudência. Seus mais profundos e dominantes sentimentos são o desejo de que o esposo volte e a repulsa por um segundo casamento. Suas principais atividades são chorar e dormir". ${ }^{1}$ A descrição não deixa de ser verdadeira, mas sabemos que ela é incapaz de dar conta da caracterização da esposa de Odisseu no poema. Na realidade, de todas as principais personagens homéricas - masculinas e femininas -, talvez nenhuma resista tanto a uma simples apresentação quanto Penélope. Aflita com a ausência sem fim do marido, de cujo retorno aparentemente descrê; assediada por jovens e violentos pretendentes, que almejam seu leito e o trono; e às voltas com um filho que ainda não se afirmou como homem, Penélope poderia ser apenas a mulher frágil e fiel, que

\footnotetext{
^andremal@uol.com.br

${ }^{1}$ Cf. Combellack, F. Three odyssean problems. California studies in classical antiquity. California, vol. VI, p. 32, 1973. As traduções são de minha responsabilidade.
} 
sofre e aguarda o desdobramento dos acontecimentos. Homero, no entanto, faz dela, ao mesmo tempo, este modelo grego de comportamento feminino e uma figura perspicaz e ativa, que contribui para o desfecho da ação, chegando a rivalizar com o próprio esposo.

Penélope parece alternar entre uma e outra posição, ora débil, ora senhora de si, ora vítima, ora condutora do destino, de tal forma que não conseguimos apreender, em definitivo, quem ela de fato é. Essa indecisão é um dos mais brilhantes efeitos criados pelo poema: por si só, se bem manejada, ela pode contribuir para adensar qualquer personagem literário, conferindo-lhe mais verdade; atrelada, porém, a uma figura feminina, com toda a sua carga de sexualidade e poder de atração, essa indecisão parece ser potencializada, porque recato e sedução simultaneamente se atraem e repelem. O segredo de Penélope reside no modo hesitante pelo qual a vemos, em certos momentos, como refém dos acontecimentos, e, em outros, como aquela que os domina por completo. Esses dois comportamentos parecem incompatíveis e, no entanto, o poema os combina de tal maneira que Penélope não surge, para nós, como figura incongruente ou esquizofrênica, mas sim como uma mulher complexa e rica. ${ }^{2}$

$\mathrm{Na}$ circunstância em que se encontra - com o marido ausente, um filho ainda imaturo e uma centena de jovens a cobiçá-la -, a indecisão apresenta-se, inicialmente, como o regime: Penélope vive na fronteira entre casamento, viuvez e novas bodas, situação que ela perpetua com a esperança de que se resolva favoravelmente. Seu ânimo está dividido (díkha thumós, XVI, 73 e XIX, 124) e podemos falar, com Norman Austin, num "conflito mental", de quem ora "está convencida de que o marido morreu", ora "recusa-se a aceitar essa conclusão". ${ }^{3}$ Sendo assim, Telêmaco é capaz de afirmar que "ela nem nega o odioso casamento nem consegue/ tomar decisão" (I, 249-250). Uma saída imediata, segundo Mentes-Atena, seria voltar para a casa paterna, para que, a partir daí, se procedesse a uma corte adequada (I, 275-278). Tanto Antínoo quanto Eurímaco pedem, efetivamente, que o filho mande a mãe para Icário, para que se providencie o casamento (II, 113-114 e 194-196) - ainda que Telêmaco tenha dito que os pretendentes preferem não trabalhar com

\footnotetext{
${ }^{2}$ Para uma abordagem geral das mulheres na Odisseia, e especialmente Penélope, cf. Said, S. Homer and the "Odyssey". Translated by Ruth Webb. Oxford: Oxford University Press, 2011, p. 258-314.

${ }^{3}$ Cf. Austin, N. Archery at the dark of the moon. Poetic problems in Homer's "Odyssey". Berkeley: University of California Press, 1975, p. 233-234.
} 
essa possibilidade (II, 52-54). Essa resolução, no entanto, deveria partir da própria Penélope, como dá a entender o jovem (II, 130-137).

Com a autonomia que a posição de senhora do lar lhe confere (déspoina: XIV, 127; XV, 374 e 377; XIX, 83; XXIII, 2), Penélope aposta a princípio na espera, sem abrir mão completamente de um eventual novo casamento, socialmente necessário e justificável no caso da morte de Odisseu - ainda que, em havendo a escolha de um pretendente, ela possa ser alvo da censura popular. ${ }^{4}$ Vejam-se estas palavras ao mendigo/ Odisseu no Canto XIX:

Pois não sei se hei de ficar com meu filho e tomar conta da minha riqueza, das servas e do alto palácio, respeitando o leito do marido e a vontade do povo; ou se deva seguir aquele dentre os acaios que for o melhor, que faz a corte no palácio e oferece incontáveis dádivas nupciais. ${ }^{5}$

(XIX, 525-529)

Portanto, "não desistir de adiar as bodas" (II, 204-205) surge como a única saída para que se mantenha aberta a possibilidade de retorno sem descartar a nova união -, apesar da tensão, do desgaste e do consumo dos bens. Nesse sentido, trata-se de uma escolha deliberada que, paradoxalmente, baseia-se na ausência de escolha.

A essa indecisão central para a ação do poema vem se juntar uma hesitação entre esperança e desespero. $\mathrm{O}$ ato de Penélope é de quem acredita ainda num desfecho positivo, mas de maneira geral a percebemos como uma mulher que não crê mais no retorno do marido - como, aliás, acontece com Telêmaco e Eumeu -, levando sua descrença às últimas consequências na parte final da narrativa.

\footnotetext{
${ }^{4}$ Para uma discussão da situação de Penélope, com remissão ao procedimento padrão, nesses casos, durante o Período Clássico, cf. Katz, M. Penelope’s renown. Meaning and indeterminacy in the "Odyssey". Princeton: Princeton University Press, 1991, p. 35-39. O fato de Atena ter levantado, na conversa com Telêmaco, a possibilidade de ele mandar a mãe de volta para a casa do pai (I, 292) associa-se à sua eventual condição de filho maduro e emancipado, e comprovadamente sem pai. Seu amadurecimento, efetivamente, vai representar uma pressão a mais para Penélope: "Está claro que a presença continuada de Penélope na casa é incompatível com o acesso completo de Telêmaco à idade adulta" (cf. Katz, op. cit., p. 35). Outro trabalho esclarecedor é o artigo de Lacey, W. Homeric "hédna" and Penelope's "kúrios". The journal of Hellenic studies. London, vol. LXXXVI, p. 62-63, 1966.

${ }^{5}$ Todas as citações da Odisseia são tiradas da versão de F. Lourenço (Lisboa: Cotovia, 2003).
} 
Repare-se no que diz Telêmaco logo no Canto I, chamando atenção para o movimento que a mãe faz em busca de notícias de Odisseu: "(...) nem ligo pra qualquer profecia que minha mãe/ a um profeta pergunte, após chamá-lo ao palácio” (I, 415-416). Eumeu, no Canto XIV, diz ao mendigo Odisseu que Penélope "recebe com gentileza e tudo pergunta" aos viajantes que chegam a Ítaca (128), mais uma vez na expectativa de conseguir informações sobre o paradeiro e a possível volta do esposo. A passagem dos anos - combinada com as mentiras contadas por esses forasteiros, que, necessitados de comida, falam o que a rainha quer ouvir (XIV, 124-125) - serve no entanto para tirar de Penélope a esperança, e por isso a ouvimos falar que o marido está morto (IV, 724 e 813). Ainda que no Canto XVII sua esperança pareça aumentar, quando o filho lhe conta que o pai está vivo (108-149) e ela ouve as palavras do vidente Teoclímeno (152-165) - de que Odisseu já está em sua pátria -, a rainha persiste em sua postura cautelosa e desconfiada, podendo mesmo desejar, com a imaginada morte do esposo, a própria morte (XVIII, 201-205; XX, 61-65).

Do mesmo modo como se chocam esperança e desesperança, também o fato de Penélope ser a única responsável por decidir ou não por novas bodas contrasta com uma passividade acentuada sua, que a deixa numa posição quase marginal. Sabemos que Telêmaco esconde da mãe a viagem a Pilos e Esparta, para que ela "não desfigure o belo rosto com o pranto" (II, 376). No Canto IV, percebemos o acerto da decisão: ao saber da partida do filho e do plano dos pretendentes de emboscá-lo, Penélope é tomada por "dor dilacerante" (VII, 16) e, depois, criticada por Euricleia por querer incomodar o velho Laertes (735-755). Sem se alimentar (ásitos, 788), ela evidencia não ter conhecimento da transformação por que passa o filho (816-817), ainda que, como ele, dependa também da intervenção de Atena, que a reconforta através de um sonho no qual garante que Telêmaco recebe a proteção dela, Atena (824-828). O interessante é notar que, nessa aparição noturna, o fantasma de sua irmã Iftima nega-se a dizer - diante do pedido da sofrida Penélope - se Odisseu está vivo ou morto (835-836), postura que, como a de Telêmaco, parece pôr a esposa à margem do desenvolvimento central da ação, como se fosse mera espectadora, fadada a chorar, dormir e pouco ou nada saber.

Quando ela reaparece no Canto XVI, mostrando-se mais uma vez aos pretendentes e dirigindo-lhes pela primeira vez a palavra (na censura a Antínoo), é ainda em prantos que a vemos (409-451), de tal modo que mais à frente pode dizer a Telêmaco que ela se deita num leito "de lamento" (stonóessa, XVII, 102). Odisseu já está em Ítaca, e essa 
informação - franqueada no Canto XV ao filho - é estrategicamente omitida por Telêmaco no momento em que, como vimos, conta à mãe apenas que o pai vive. Penélope, assim, é reafirmada nessa posição feminina, quase infantilizadora, de quem é privada do conhecimento do que de fato se passa.

As referências a ela no Canto XI, feitas a Odisseu pela mãe do herói, Anticleia, e por Agamêmnon, insistem no quadro de uma mulher chorosa (181-183) - mas resistente - e da qual se devem ocultar os planos; a fala do Atrida (441-456), no entanto, complica o que poderia ser uma simples apresentação dessa passividade, porque se indica, por um lado, que Penélope deve permanecer à margem das decisões ("Não lhe declares todo o pensamento que tiveres,/ mas diz-lhe só alguma coisa, ocultando o resto"), por outro também chama atenção para seu poder de discernimento, de mulher circunspecta ("pois é muito prudente e bem conhece planos na mente/ a filha de Icário, a circunspecta Penélope"). Por essas palavras percebemos como a esposa de Odisseu é uma figura ambígua, passiva e ativa, ignorante e esperta, leal e sujeita à traição. ${ }^{6}$ A oposição geral a Clitemnestra não impede que sintamos alguma similaridade latente. Como apontou Marylin Katz, ao discutir o passo citado, "o elogio de Penélope e as garantias de sua fidelidade vêm enquadrados por advertências e inseridos num quadro geral de desconfiança e traição". 7 Os acontecimentos envolvendo Egisto e Orestes, ao fazerem incidir luz negativa também sobre Clitemnestra, trazem repercussões novas para a história da Odisseia. Como diz ainda a mesma Marylin Katz (que chama atenção para o uso de termos semelhantes para a caracterização tanto de Clitemnestra quanto de Penélope; III, 266 e XXIV, 194):

O mito da casa de Atreu foi agora expandido para servir de paradigma para um possível desfecho negativo da situação de Penélope, e a expansão é formulada em termos que tornam possível acomodar Penélope dentro desses limites: ela, assim como Clitemnestra, é

\footnotetext{
${ }^{6}$ Douglas Stewart sugere, de modo divertido, um possível "sentido obsceno" no verso 445, já que o termo que traduzimos por "planos" (médea) é idêntico, em grego, ao utilizado para indicar a genitália... Cf. Stewart, D. The disguised guest. Rank, role, and identity in the "Odyssey". Cranbury: Associated University Press, 1976, p. 60.

${ }^{7}$ Cf. Katz, op. cit., p. 52. Na mesma página, como costuma fazer ao longo de todo o livro, Katz discute as suspeitas dos analistas em relação à lógica desses versos homéricos.
} 
uma mulher de "bom espírito" (agathai phrénes); ela está agora, como antes estava Clitemnestra, sem supervisão masculina. ${ }^{8}$

Portanto, ao mesmo tempo em que a vemos sofrendo pela ausência do marido e peripécias do filho, alheia aos planos masculinos e entregue ao choro e ao sono - "todos os dias me comprazo em lamentar, prantear", diz ela ao mendigo/ Odisseu (XIX, 513) -, vemo-la também como alguém capaz de empregar a inteligência para dirigir as ações e reafirmar sua condição de senhora do lar, responsável por decidir o próprio futuro.

$\mathrm{Na}$ Odisseia, como se sabe, dois estratagemas pintam de maneira inequívoca esse seu lado esperto, astuto e perigoso, lado que, combinado ao comportamento feminino tradicional, faz dela uma figura ambivalente e enigmática. O primeiro estratagema é o da mortalha: ele é anterior à ação do poema, mas vem rememorado três vezes na narrativa (Cantos II, XIX e XXIV); o segundo, mais problemático, é o desafio do arco, mencionado pela primeira vez no Canto XIX e fundamental para decidir a vitória de Odisseu sobre os pretendentes. Juntos, eles nos mostram que a perspicácia não é uma característica que Penélope adquire apenas na parte final do poema, como se, à maneira do filho, ela se transformasse e em certo sentido "amadurecesse" ao longo da narrativa. ${ }^{9}$ Na realidade, o que podemos depreender dessas ações é que a medida estratégica faz parte do seu comportamento diante da situação adversa, e que ela lança mão desse recurso para, assim como o marido, tentar vencer os pretendentes pela astúcia.

O primeiro ardil consistia em propor aos pretendentes que esperassem que concluísse a mortalha de Laertes, para aí sim tomar uma decisão: de dia ela tecia a veste em seu tear, mas à noite secretamente a desfazia. A trama estendeu-se por três anos e foi descoberta porque uma das escravas delatou a senhora, que - pega em flagrante - se viu obrigada a terminar o trabalho "contra a vontade, à força". Antes e depois de Antínoo relatar o acontecido, no Canto II (93-110), ele põe em destaque a esperteza de Penélope: não apenas diz que se trata de um

\footnotetext{
${ }^{8}$ Cf. Katz, op. cit., p. 45. Ambas foram deixadas aos cuidados, respectivamente, de Mêntor (Od. II, 226-227) e um cantor (Od. III, 267-268). Cf. também XV, 19-26, quando Atena, para exortar Telêmaco, fala que a mãe pensa já em outro casamento, e Katz, op. cit., p. 61.

${ }^{9}$ Não concordo com a afirmação de M. Katz de que, até o reconhecimento entre Telêmaco e Odisseu, a conduta de Penélope é "inteiramente unidimensional", e que a ambiguidade só se estabelece a partir do Canto XVIII (cf. Katz, op. cit., p. 119).
} 
"ardil" (dólos, 93) dela, que assim "frauda" (atémbei, 90) os seus cortejadores, mas também chama atenção para a ligação da mulher de Odisseu com Atena, que lhe concedeu "ser versada em belíssimos lavores, belo pensar/ e coisas vantajosas (kérdea), tal como ainda não ouvimos nenhuma ser, nem das antigas" (117-118), o que lhe trará "grande fama" (méga kléos, 125), ainda que seja - da perspectiva de Antínoo - um comportamento ruinoso, indevido, não enaísimon (122).

Quando é a vez de Penélope rememorar a história, para o mendigo Odisseu, no Canto XIX (137-156), mais uma vez o ardil é associado à reflexão sobre sua glória (kléos, 108-128), mas Atena não é referida: segundo Penélope, "foi um nume que inspirou" (enépneuse daímon, 138) a ideia, e "tecer o manto" (phâros... huphaínein, 138-139) equivale a "tramar ardis" (dólous tolupeúo, 137). A conclusão seguinte nos prepara para a proposição do desafio do arco, ao mesmo tempo em que indica o comportamento ardiloso característico, de quem está sempre às voltas com uma saída inteligente para as dificuldades em que se encontra: "Agora já não consigo fugir ao casamento, nem uma outra/ astúcia (mêtin, 158) encontro ainda (...)". O relato de Anfimedonte, um dos pretendentes mortos, no Hades (XXIV, 128-146), ${ }^{10}$ traz, como informação nova, a indicação de que a chegada de Odisseu ocorreu logo depois de Penélope ter concluído a mortalha (147149), dando assim mais precisão cronológica ao que aparentava ser um fato vago do passado e reforçando a premência de uma solução esperta, que contenha a ansiedade e violência dos pretendentes. ${ }^{11}$

Assim, com essa estratégia, Penélope simultaneamente apresenta - ao menos por um tempo - para os pretendentes a visão da mulher passiva, sob controle, e da mulher esperta, que age e premedita. Há, em outros termos, um jogo aí entre aparência e essência, entre a expectativa que se cria e a real intenção que se oculta - motivo central a atravessar todo o poema e, de diferentes formas, suas personagens principais. Portanto, a trama da mortalha nos revela que adiamento e indecisão, longe de indicarem falta de recursos, estão associados a um plano, e que a mulher aparentemente incapaz é dotada de uma esperteza afim à do marido. Repare-se como essa ideia vem sublinhada nos versos

${ }^{10}$ Cf. II, 94-107 = XIX, 139-152 = XXIV, 129-142. As três versões têm variações na abertura e na conclusão. Para uma comparação, cf. de Jong I. A narratological commentary on the "Odyssey". Cambridge: Cambridge University Press, 2001, p. 50-51.

${ }^{11}$ Combellack insiste nessa questão cronológica, propondo que o intervalo entre a fraude descoberta e a chegada de Odisseu tenha sido de aproximadamente um mês (cf. op. cit., p. 34). 
ditos por Antínoo imediatamente antes de discorrer sobre o truque de Penélope: "a todos dá esperança e a cada um faz promessa,/ mandando recados, mas sua mente anseia outras coisas (álla menoinâi)"(II, 91-92).

Essas linhas vêm depois repetidas por Atena, no seu diálogo com Odisseu no Canto XIII (379-381), e o hemistíquio final do verso 92 - "mas sua mente anseia outras coisas" - é dito pelo narrador no Canto XVIII (283, agora com o verbo no passado, “ansiava”), ao falar da alegria de Odisseu em ver a mulher arrancando presentes dos pretendentes sem que eles suspeitassem de suas intenções. É importante não só notar o contraste entre o que ela faz e o que intenciona, mas a presença das ideias de "mente" (nóos) e "furor" (ménos, contida no verbo de mesma raiz menoináo, "ansiar"), que aproximam Penélope do universo masculino de Odisseu e Telêmaco. ${ }^{12}$

Antes de passarmos para a discussão do segundo estratagema - o desafio do arco -, no qual o dado da intenção oculta é mais complexo, vejamos rapidamente a participação de Penélope entre os Cantos XVI e XVIII. Já notamos a continuidade do comportamento choroso e em geral desesperançado. Com a chegada do mendigo Odisseu, contudo, Homero passa a explorar uma espécie de ironia positiva nas palavras de Penélope, de tal modo que ela pressente a realidade relativa à volta do marido e à destruição dos pretendentes. Mais uma vez, mesmo diante da passividade e falta de conhecimento em relação ao sentido de algumas de suas palavras, percebemos a mulher capacitada a iludir e falar com propriedade. Vejase, a esse respeito, o que diz ao saber da agressão de Antínoo ao pedinte - "Que desse jeito te atinja Apolo do arco famoso" (XVII, 494) -, ou sua disposição em interrogar o misterioso estrangeiro, que, segundo ela mesma diz, lhe parece "muito viajado" (polúplagktos, 511). A essa afirmação

${ }^{12}$ Para alguns a frase "a mente anseia" indica uma operação menos mental e mais passional (algo como "a mente deseja com intensidade”). Cf. Byre, C. Penelope and the suitors before Odysseus: "Odyssey" 18.158-303. The American journal of philology. Baltimore, vol. CIX, n. 2, p. 166 e 171-172, 1988. É o que defende Uvo Hölscher, para quem não se pode ler aí nenhuma intenção secreta; cf. em seu "Penelope and the suitors" (translated by Simon Richter). In: Schein, S. (Org.). Reading the "Odyssey". Selected interpretive essays. Princeton: Princeton University Press, 1996, p. 135-136. No fim das contas a nuance não altera, me parece, o sentido geral; cf. também o que diz Katz, op. cit., p. 90. R. Nickel defende, de modo persuasivo, que as três passagens ajudam a manter a incerteza sobre Penélope (internamente e também para nós, leitores e ouvintes) e, que, no caso de Atena, não se pode dizer que ela garante para Odisseu a lealdade da esposa; cf. seu Athene, Penelope and the vengeance plot against the suitors. Quaderni Urbinati dicultura classica. Urbino, vol. XCVI, n. 3, p. 29-54, 2010. 
involuntariamente verdadeira vem se juntar outra, de que o forasteiro não é "insensato" (áphron, 586), num jogo de ironias que a contrapõe a Odisseu; este, com domínio total da situação, pede a Eumeu que a entrevista com a senhora ocorra apenas ao pôr do sol (para evitar a presença dos pretendentes), mas garante que falará sem erro: "Sei tudo sobre ele [Odisseu]: enfrentamos o mesmo sofrimento" (563)! $!^{13}$

Essa situação não rebaixa Penélope, porque, como já se notou, sua qualidade de "circunspecta" nos permite enxergar uma mulher sinuosa, manipuladora como o marido. No Canto XVIII, a aproximação entre o casal vai se tornando mais evidente, ainda que a primeira conversa de fato ocorra só no Canto XIX. Assim como acontece com Odisseu, é por uma deliberação de Atena que ela decide se mostrar aos pretendentes para deles arrebatar mais dádivas (XVIII, 158-162); e, assim como acontece com Odisseu, é por intervenção de Atena que ela sofre uma transformação física (187-196); o resultado é um aumento do desejo dos jovens cortejadores (212-213), ainda que Penélope reafirme seu recato (aidéomai, "tenho vergonha", 184).

Interessante, em toda a passagem, é a menção de seu riso no momento em que comunica a Eurínome o desejo de aparecer novamente perante os homens (163). Embora o trecho seja de difícil interpretação - ajudando assim a compor o caráter indecifrável de Penélope -, sigo, nesse ponto, Daniel Levine: o riso "inútil" ou "sem propósito" (akhreîon), longe de marcar incerteza ou perplexidade, parece manifestar confiança e é uma reação apropriada diante da perspectiva de enganar, com sucesso, os pretendentes. ${ }^{14}$ No conjunto maior dessa parte da narrativa, ele vem

\footnotetext{
${ }^{13} \mathrm{~W}$. Stanford chama atenção para um possível jogo aí com o adjetivo homén, que pode ser entendido, em grego, como "o mesmo"/ "idêntico" ou "similar". Cf. Stanford, W. Ambiguity in Greek literature. Oxford: Basil Blackwell, 1939, p. 107.

${ }^{14}$ Cf. Levine, D. Penelope's Laugh: "Odyssey" 18.163. The American journal of philology. Baltimore, vol. CIV, n. 2, p. 174, 176 e 178, 1983. Quanto a akhreîn, parece-me que C. Byre está correto ao dizer que o advérbio tem o sentido evidente de "sem alvo", como se vê pela outra única ocorrência sua em Homero, quando Tersites, "com dor, olhando sem propósito (akhreîon idón), enxugou as lágrimas” (Il. II, 269); mas discordo da sua visão de que, na passagem em questão, ele indica a incapacidade de ação de Penélope; cf. Byre, op. cit., p. 162-163. A interpretação para o termo de Jenny Strauss Clay (que concorda com a leitura geral de Levine) não deixa de ser interessante: akhrêion significaria "de modo não característico" e, portanto, tanto Penélope quanto Tersites estariam com comportamentos que destoam do seu habitual. Cf. Clay, J. S. Homeric "akhreîon”. The American journal of philology. Baltimore, vol. CV, n. 1, p. 73-76, 1984.
} 
se juntar ao riso de Penélope diante do espirro auspicioso de Telêmaco no Canto XVII (542); ao sorriso "sardônico" (sardánion) de Odisseu no Canto XX (301-302), ao evitar o pé de boi arremessado por Ctesipo; e ainda ao riso de Telêmaco no Canto XXI (105). Temos aí o espelhamento com a ação dos pretendentes - também espertos, também dissimulados e também risonhos -, mas em chave positiva: no caso de Telêmaco, Penélope e Odisseu, essas estratégias ligam-se a um fim justo, sancionado pela justiça de Zeus. ${ }^{15}$

Finalmente, a reforçar a sintonia de Penélope e Odisseu - ambos astutos e pacientes -, temos, ainda nesse Canto XVIII, a referência ao diálogo que teve com o esposo vinte anos atrás, no momento em que ele partia para Troia (257-273). O episódio é fundamental para percebermos não apenas que, dramaticamente, o amadurecimento de Telêmaco funciona como motivação importante para a posterior proposição do desafio do arco ("E quando vires que meu filho tem a barba a despontar,/ desposa quem tu quiseres. Então deixa a tua casa", 270-271), mas também que essa decisão, de certo modo, está de acordo com a vontade de Odisseu: mais uma vez, parece que é o entendimento entre marido e mulher que vem sublinhado. ${ }^{16}$ Por outro lado, o fato de Penélope se considerar "funesta" (ouloménes, 273) e privada da felicidade concedida por Zeus, entendendo que "tudo se cumpre" segundo as piores previsões, reaviva em nós a percepção da desesperança e da expectativa sua de uma total separação do marido.

É essa tensão - entre a mulher que nada sabe da volta de Odisseu e do que se passa, acreditando-se fadada a "bodas odiosas", e a mulher que, inversamente, parece pressenti-la de um modo oculto, encaminhando-se para o reencontro com o esposo - que está no centro da discussão sobre os Cantos XVIII e XIX e, mais especificamente, a respeito da proposta do desafio do arco. O problema, em outras

\footnotetext{
${ }^{15}$ Daniel Levine mostra como o sorriso de Odisseu em Od. XX, 301-302 vem se juntar a outros dois, tendo a função de indicar, nessa parte da narrativa, sua "superioridade confiante", de "aposta no sucesso"; cf. Odysseus' smiles: "Odyssey" 20.301, 22.371 e 23.111. Transactions of the American philological association. Baltimore, vol. CXIV, p. 1-9, 1984. Sobre o sentido de sardánion, ver, no mesmo artigo, p. 4-5 e notas 11-14.

${ }^{16}$ Sigo Uvo Hölscher, que vai contra aqueles que, como U. Wilamowitz e K. Reinhardt, propõem que o diálogo é uma invenção de Penélope. Não concordo, no entanto, com sua tentativa de desconsiderar uma possível esperteza por parte da mulher de Odisseu, nem com a abordagem mais genética, preocupada em apontar como se teria dado a transformação dos elementos do "conto popular" em "épica"; cf. op. cit., p. 134-135.
} 
palavras, consiste em se determinar se há ou não o reconhecimento do marido por parte de Penélope. ${ }^{17}$ Que ela será excluída de um reconhecimento imediato fica dito pelo narrador no Canto XIII, logo que Odisseu acorda em Ítaca: "Palas Atena, filha de Zeus, derramara uma neblina/ para o tornar irreconhecível e para lhe explicar tudo primeiro,/ para que a esposa, os cidadãos e amigos não o reconhecessem/ antes de ele castigar toda a transgressão dos pretendentes" (XIII, 190193). Mais adiante, ele diz para o filho, depois de se revelar: "Se na verdade és meu filho e do nosso sangue,/ que ninguém fique a saber que Odisseu está em casa:/ que nem Laertes saiba, nem o porqueiro,/ nem qualquer um dos servos, nem Penélope" (XVI, 300-303).

Essa exclusão parece, a princípio, ilógica, porque coloca Penélope no mesmo plano de ignorância dos jovens que a cobiçam, além de resultar na perda daquela que seria uma aliada importante para a execução da vingança. Como afirma Sheila Murnaghan, "precisamente a pessoa cuja cooperação é a mais essencial para o sucesso de Odisseu - Penélope não fica inteirada da trama até que ela esteja concluída. Tal como os pretendentes, ela faz parte de uma trama de cujo conhecimento fica excluída". ${ }^{18}$ A mesma Murnaghan, no entanto, busca as motivações dramáticas para essa opção. Uma primeira explicação estaria na própria misoginia do poema, a refletir um aspecto destacado da cultura grega antiga. Sendo assim, a desconfiança em relação à mulher segue a norma (e, portanto, o reconhecimento por parte de Euricleia só pode ser apresentado como algo acidental). Outro ponto importante, que nos ajuda a entender o porquê dessa opção, é o quanto a narrativa ganha em interesse - como estamos vendo - com esse jogo de ocultação entre Penélope e Odisseu, que Homero faz questão de estender ao máximo. Ainda segundo Murnaghan, "o relato dos encontros do casal [anteriores ao reconhecimento final] possibilita efeitos de ironia e um quadro atrativo da crescente cumplicidade psicológica entre Penélope e o estrangeiro". ${ }^{19}$

Uma terceira e última explicação possível diz respeito à própria caracterização de Penélope: sem que Odisseu se revele a ela - e com o narrador nos dizendo que a revelação deverá ocorrer apenas depois do massacre dos pretendentes -, podemos imaginar que suas ações, nessas

\footnotetext{
${ }^{17}$ Para um panorama das leituras propostas, cf. Capítulo IV ("What Does Penelope Want? Books 18, 19”), p. 77-113, do já citado livro de Katz.

${ }^{18}$ Cf. Murnaghan, S. Disguise and recognition in the "Odyssey". Princeton: Princeton University Press, p. 118.

${ }^{19}$ Cf. Murnaghan, op. cit., p. 119.
} 
circunstâncias, vão reafirmando suas castidade e fidelidade, ao mesmo tempo em que as colocam em risco. É isso, no final das contas, que o desafio do arco representa no poema: estratagema decisivo para o desfecho favorável (com a fiel Penélope dele saindo intacta), mas também disputa capaz de dar a ela um novo marido e as "bodas odiosas". Com a revelação prévia de Odisseu, Penélope seria apenas mais uma cúmplice sua; com a não-revelação, ela ainda parece agir como uma cúmplice ainda que às cegas -, mas há espaço para pensarmos que suas intenções podem ser outras... Sua "duplicidade" sai assim reforçada, e isso só é possível porque, no poema, o narrador onisciente não nos franqueia as intenções reais da esposa de Odisseu. Apesar de informados de que a revelação entre marido e mulher só acontecerá tardiamente, somos levados, pelas falas e ações de Penélope, a imaginar que talvez ela já tenha descoberto a verdade; para esse efeito, contribui decisivamente essa atuação do narrador, mais discreto do que o habitual. Será que, assim como fazem Odisseu e Telêmaco com ela, Penélope é capaz de ocultar do filho e do marido suas intenções, deixando-os à margem? Podemos pensar que sim e que não. Sobre esse seu comportamento ambíguo, diz Sheila Murnaghan:

Se ele for visto como algo que conduz ao acontecimento central da história - seu reconhecimento por Odisseu -, ele é então consonante com uma ação que a define como inabalavelmente leal, perspicaz e com o controle do seu destino (...). Mas se suas ações forem vistas como refletindo o fato de que não sabe para onde se encaminham os acontecimentos, elas não parecem mais revelar essas mesmas características supostamente constantes. ${ }^{20}$

Com efeito, antes da proposta do desafio do arco, ela se mostra simultaneamente perdida e atenta na conversa com o mendigo Odisseu. Veja-se como, na cena, a princípio é ele quem tem o controle total da situação, disposto que está a "provocar" (erethízo, 45) a esposa: depois de contar suas "mentiras", a mulher se desfaz em lágrimas, mas o marido se mantém firme; Penélope, no entanto, faz a desconfiança e a esperteza contrastarem com essa fragilidade:

\section{(...)}

chorando pelo marido, que estava à sua frente.

Odisseu sentiu pena no coração da mulher que chorava;

${ }^{20}$ Cf. Murnaghan, op. cit., p. 128-129. 
mas nas pálpebras manteve os olhos imóveis, como se fossem de ferro ou de chifre; e com ardil ocultou as lágrimas.

Depois de ela ter-se saciado com o pranto de lágrimas copiosas, de novo lhe dirigiu a palavra em resposta ao que fora dito:

"Agora, estrangeiro, tenho de te pôr à prova, para averiguar se na verdade com os divinos companheiros deste hospitalidade ao meu marido lá no teu palácio, conforme afirmas.

Diz-me como eram as roupas que ele tinha no corpo; diz-me como ele era e como eram os seus companheiros". Respondendo-lhe assim falou o astucioso Odisseu: "Senhora, é difícil dizer ao certo, após tanto tempo. É já o vigésimo ano desde que ele chegou e depois partiu da minha pátria. Mesmo assim tentarei dizer-te como o imagino no meu coração”. (...)

(IX, 209-224)

Ela não sabe que tem diante de si o esposo pelo qual chora, mas o expediente que emprega é característico de Odisseu: no Canto XIII Atena dissera que ele também quer testar a mulher: "Mas tu não desejas nem saber nem inquirir, antes de teres/ posto à prova tua mulher" (335-336). Se ela é, afinal, como ele, a dissimulação pode fazer parte de suas ações - embora, ao contrário do que faz com seu herói, Homero não a sinalize abertamente para nós. Sabemos que Penélope é esperta, na mesma medida em que não sabemos se há dissimulação de sua parte. Repare-se como, dentro da construção dessa sintonia com o marido e dessa duplicidade (que ameaça a sintonia), no mesmo Canto XIX ela é capaz de se mostrar mais uma vez descrente da volta de Odisseu ("prouvera que tal palavra se cumprisse", 309, "não virá mais para casa", 313, "se é que existiu", 315) e, simultaneamente, detentora de autoridade e inteligência, alguém com "mente" (nóon) e "astúcia" (mêtin) que a põem acima das demais mulheres (325-326). Mais adiante, ela ainda pode se referir ao estrangeiro como "caro" (phíle, 350, philíon, 351) e ressaltar seu caráter "ponderado" (pepnuménos, 351, pepnuména, 352), nos levando a evocar os laços familiares....

Que um possível reconhecimento se insinua nesse ponto do poema sugerem não só os versos em que o poeta fala que ela reconhecera os sinais (as roupas) indicados por Odisseu - o verso 250 é idêntico ao 206 do Canto XXIII, quando ela definitivamente o reconhece -, mas também

${ }^{21}$ Cf. Stewart, op. cit., p. 113-114. 
as seguintes linhas, no momento em que se dirige a sua serva: "Vamos, levanta-te agora, circunspecta Euricleia,/ lava os pés de quem tem a idade do teu amo. De Odisseu/ decerto tais já são pés, e também as mãos:/ depressa os mortais envelhecem em circunstâncias adversas" (XIX, 357360). Podemos ver aí apenas o efeito irônico característico deste encontro entre Penélope e o mendigo Odisseu, mas o fato de ela apontar uma semelhança física entre o estrangeiro e seu marido desaparecido - para o qual usa um inesperado e otimista tempo presente, "são" - parece forte demais para que não se crie em nós a suspeita de que a verdade foi descoberta, sobretudo porque, poucos versos antes, o "mendigo" falara a Penélope que Odisseu fora ao oráculo de Dodona para saber se regressaria a Ítaca "às claras ou disfarçado" (kruphedón, 299). ${ }^{22}$ De qualquer maneira, o que temos, na sequência, é de fato um reconhecimento, não por parte de Penélope, mas de Euricleia, que, ao lavar os pés do forasteiro, reconhece a cicatriz de Odisseu. Como apontou Marylin Katz, é como se o processo de reencontro fosse interrompido - em relação a Penélope -, ao mesmo tempo em que se concretiza na figura da ama, que, talvez não por acaso, recebe aqui pela única vez o epíteto da senhora, "circunspecta" (períphron). ${ }^{23}$ Sheila Murnaghan fala numa combinação de um nível superficial com outro, subterrâneo:

No nível superficial da trama, Odisseu não revela sua identidade a Penélope, e ela não o reconhece antes de resolvido o problema com os pretendentes. Mas, em termos dos padrões que suas ações perfazem, Odisseu e Penélope participam de uma série de encontros em que fazem os movimentos do reconhecimento, com um aceitando o outro, o que antecipa e conduz ao reencontro explícito no Canto XXIII. Esses encontros representam, em certo sentido, cenas de reconhecimento subterrâneas: assemelham-se ao momento de reconhecimento explícito que antecipam, mas não compartilham da sua explicitude. ${ }^{24}$

\footnotetext{
${ }^{22}$ Cf. Harsh, P. Penelope and Odysseus in "Odyssey" XIX. The American journal of philology. Baltimore, vol. LXXI, n. 1, p. 14, 1950, é quem chama a atenção para o detalhe, com o intuito de defender a posição de que Penélope reconhece o marido já nesses encontros dos Cantos XVIII e XIX.

${ }^{23}$ Cf. Katz, op. cit., p. 133-134. As ironias continuam; vejam-se estes versos em que Homero faz com que, na fala da serva, ela involuntariamente confunda a segunda pessoa do singular (primeiro usada em referência a Odisseu, depois ao "mendigo"), no momento em que vê uma possível identidade entre eles (XIX, 363-372). A resposta de Odisseu não fica atrás (XIX, 383-385).

${ }^{24}$ S. Murnaghan, op. cit., p. 52.
} 
$\mathrm{Na}$ retomada da conversa entre Penélope e o mendigo, é a vez de o relato do sonho operar como mais um indicador da complexidade dessa figura feminina - de suas motivações e intenções. A passagem é complexa porque a visão noturna, embora traga uma perspectiva claramente favorável para Penélope - a morte dos pretendentes -, vem desacreditada por ela. Mais do que isso: os animais mortos no sonho, que são identificados com os jovens que a cortejam no palácio, são queridos à senhora, que sofre com sua destruição. Retomemos rapidamente o relato feito por Penélope ao mendigo nesse trecho (535569), com o intuito de que ele fizesse sua interpretação (hupókrinai, 535): no sonho (ocorrido num tempo não especificado), os vinte gansos que tem em casa são mortos por uma águia; ${ }^{25}$ ela chora, mas é tranquilizada pela águia, que lhe diz que a visão se cumprirá: os gansos são os pretendentes e ela mesma, águia, é o marido que voltará para se vingar; depois disso, Penélope acorda e percebe que os gansos continuam vivos no palácio. ${ }^{26} \mathrm{O}$ mendigo Odisseu diz que o sonho é claro e trouxe consigo a própria interpretação: o destino dos pretendentes está selado. Penélope, no entanto, retruca que os sonhos são "confusos" (akritómuthoi, 560): eles podem passar pelo portão de chifres (keráon, 566) - os que se cumprem (kraínousi, 567) - ou pelo

\footnotetext{
${ }^{25} \mathrm{O}$ número vinte parece indicar aí apenas uma quantidade significativa, como em XIV, 98, XX, 158 e XXII, 57, o que talvez sirva para explicar o fato de Helena afirmar, em Il.XXIV, 765, que já fora raptada havia vinte anos (e não dez, como esperaríamos). Cf. Rozokoki, A. Penelope's dream in book 19 of the "Odyssey". The classical quarterly. Watford, vol. LI, n. 1, p. 2, 2001. Já Louise Pratt, em seu artigo “Odyssey” 19.535-550: on the interpretation of dreams and signs in Homer. Classical philology. Chicago, vol. LXXXIX, n. 2, p. 147-152, 1994, propõe que o número vinte seja identificado, com base em Il. II, 308-320, com os anos que Penélope passou sem Odisseu, e que a morte dos gansos, animais símbolos da fidelidade, representaria a destruição do lar, o que justificaria, do ponto de vista dela, uma acolhida negativa do sonho. A associação com o número de anos já havia sido feita por Peter von der Mühll, e rebatida por Philip Harsh, que entendia "vinte" apenas como uma quantidade "indefinidamente grande"; ver op. cit., p. 1, nota 2.

${ }^{26}$ Também em XV, 160-178, o voo de uma águia, segurando em suas garras um ganso, permite o mesmo paralelismo, na interpretação de Helena, Odisseu/ águiapretendentes/ ganso. A diferença fica por conta da presença de um só ganso no Canto XV, na verdade uma "gansa" (no feminino), o que poderia indicar mais a licenciosidade estabelecida na ausência de Odisseu do que os cortejadores de Penélope, conforme propõe A. Rozokoki, op. cit., p. 2, nota 5.
} 
portão de marfim (eléphantos, 564) - os que iludem (elephaírontai, 565) e ela, desesperançada, imagina que o seu sonho não é verdadeiro. ${ }^{27}$

A descrença aqui pode, efetivamente, fazer parte do movimento geral e maior de desesperança e desconfiança - mesmo diante dos sinais positivos -, mas ainda assim permanecem alguns elementos que tornam a cena ambígua. O principal decorre da identificação, no sonho, dos pretendentes com os gansos domésticos, que Penélope "se alegra em contemplar" (iaínomai eisoróosa, 537). O fato de ela chorar e lamentar sua morte (com o sonoro klaîon kaì ekókuon, 541), tão intensamente de modo a despertar piedade (oîktr' olophuroménen, 543), e depois parecer demonstrar alívio ao acordar e encontrá-los vivos (552-553), ativa em nós - mas, aparentemente, não em Odisseu - a inevitável sensação de que ela se compraz com a presença dos jovens no palácio. Como afirma Joseph Russo: "A dor de Penélope foi tão enfaticamente apresentada (klaîon, ekókuon, olophuroménen), que podemos com acerto inferir que, inconscientemente, ela é consideravelmente menos hostil aos pretendentes do que frequentemente afirma em seu comportamento consciente. Num nível que nem ela mesma pode perceber, ela gosta (iáinomai) de ser cortejada”. ${ }^{28}$

Mas não é preciso invocar Freud nem a moderna ideia de desejo inconsciente para afirmar o descompasso: ainda que culturalmente os sonhos tenham na Grécia um valor profético, não sendo vistos como veículos de uma intimidade subterrânea, a dubiedade é um efeito claro da construção do texto e vem se juntar a outros elementos já vistos da caracterização de Penélope. A imagem onírica dos inimigos deriva daquilo que, no plano da realidade, é caro à senhora: essa contradição é significativa. Junte-se a isso a insistência de que é confuso e "terrível" (ainón, 568) um sonho claro - o único sonho em Homero a se "autoexplicar" - e temos novamente uma Penélope ambivalente, sintonizada com o marido (a quem confia essa informação, e cujas palavras reconfortantes ouve em sonho, por meio da águia, e acordada,

\footnotetext{
${ }^{27} \mathrm{O}$ jogo de palavras, que as traduções não conseguem reproduzir, fica evidente no texto grego. A. Rozokoki tenta explicar a simbologia - marfim $=$ engano; chifre $=$ verdade - apoiando-se na aparência mais atraente e sedutora do marfim, em oposição à simplicidade do chifre sem brilho. Cf. Rozokoki, op. cit., p. 5-6. Platão retoma a imagem dos portões em Cármides 173A.

${ }^{28}$ Cf. Russo, J. Interview and aftermath: dream, fantasy, and intuition in "Odyssey" 19 e 20. The American journal of philology. Baltimore, vol. CIII, n. 1, p. 9, 1982.
} 
por meio do mendigo), mas que resiste em acreditar num reencontro e, veladamente, pode ter prazer na corte dos pretendentes. ${ }^{29}$

É precisamente nesse ponto - não por acaso - que surge a proposta do desafio do arco. Reunida, sem que saiba, com o marido, e com bons motivos para acreditar no seu retorno, ela vem reafirmar a descrença numa possível volta e cogitar a união com um dos pretendentes; com efeito, Penélope já se imagina deixando o palácio: "Agora outra coisa te direi; tu guarda-a no teu espírito:/ está perto a malfadada aurora, que me afastará da casa de Odisseu./ Estabelecerei pois um desafio, o dos machados (...)/ Quem com mais facilidade armar o arco nas mãos/ e fizer passar a seta pelo meio dos doze machados,/ a esse eu seguirei (...)" (XIX, 570-579). Os estudiosos se perguntam se Penélope, ao cogitar essa prova, estaria agindo de maneira astuta - seja porque reconhece Odisseu, seja porque está certa de um desfecho favorável - ou se estaria de fato abrindo espaço para novas bodas, totalmente desesperançada do retorno do marido. Para Joseph Russo, Penélope "intui" que se aproxima o dia decisivo e por isso propõe o concurso. ${ }^{30}$ Para Patricia Marquardt, trata-se de uma astúcia, porque ela sabe que nenhum dos pretendentes será capaz de esticar o arco "muito facilmente" (rheítata, XIX, 577 = XXI, 75), a não ser Odisseu (rheidíos, XXI, 328 e 407, XXIV, 177). Frederick Combellack, por sua vez, considera que, no caso de se tratar de fato de um estratagema, o poema é falho nesse ponto porque, ao não revelar as intenções de Penélope, apresenta sua conduta como "ilógica" e "precipitada”. Já Marylin Katz chama a atenção - como outros já haviam feito - para a pressão que Penélope sofre diante do amadurecimento de Telêmaco, que, somada às palavras de Odisseu de quando de sua partida, conduzi-la-iam a escolher um novo marido. ${ }^{31}$

Qualquer que seja a motivação principal, parece-me que a melhor maneira de entender o movimento de Penélope é preservando sua duplicidade, elaborada por Homero com uma "astúcia de mestre", como diz Nancy Felson-Rubin, e que resulta numa incontornável "inescrutabilidade". Segundo essa estudiosa, devemos sim trabalhar com

\footnotetext{
${ }^{29}$ Não me parece fazer sentido imaginar que Penélope inventa o sonho para Odisseu, como sugere, por exemplo, Douglas Stewart, op. cit., p. 118.

${ }^{30} \mathrm{~J}$. Russo destaca já no título de seu artigo esse elemento, bem de acordo com a "força inconsciente" que quer sublinhar nesse movimento de aproximação entre Odisseu e Penélope; ver op. cit., p. 6 e 18.

${ }^{31}$ Cf. Marquardt, P. Penelope "polytropos". The American journal of philology. Baltimore, vol. CVI, p. 41, 1985; Combellack, op. cit., p. 39-40; Katz, op. cit., p. 121.
} 
a possibilidade de que ela esteja agindo de modo perspicaz, embora o texto, num nível imediato, não nos diga isso:

Homero faz com que as intenções de Penélope permaneçam não apenas complexas, mas enigmáticas, sugerindo ora que ela percebe a presença do marido ou sua volta iminente, ora que ela perdeu toda a esperança. Sua audiência, portanto, não pode excluir a possibilidade de que Penélope propõe o desafio do arco de boa fé, como uma forma de selecionar um novo marido, e que ela de fato pretende se casar de novo. A seriedade de sua proposta fica atestada pela prece dirigida a Ártemis, na qual solicita uma morte súbita (XX, 61-83), e por sua lágrimas quando examina os armamentos do marido (XXI, 5-60). ${ }^{32}$

Sheila Murnaghan, em seu livro, propõe leitura similar, dando mais ênfase, porém, ao modo como a prova traz consigo, simultaneamente, uma ameaça a Odisseu e uma possibilidade de êxito que exclui necessariamente os pretendentes. Em outras palavras, parece que se trata de um ardil, mas involuntário:

Ela estabelece como condição para a escolha do novo marido a realização de um feito que apenas seu antigo marido é capaz de realizar. O aspecto do desafio que faz com que pareça muito ameaçador e desleal para com Odisseu - o modo como é pensado para que se encontre alguém à sua altura -é na realidade o que o torna ideal para se recuperar a identidade única do esposo. O desafio, no fim das contas, não resulta num tipo de diferenciação entre os pretendentes incompatível com o triunfo de Odisseu. É porque os pretendentes ficam cegos à sua inferioridade em relação a Odisseu que eles caem na armadilha de aceitar, para se casar com Penélope, a condição que automaticamente os desqualifica e sela seu destino. No entanto, a própria Penélope não parece ciente da armadilha preparada para os pretendentes. ${ }^{33}$

Mas será mesmo que Penélope propõe o desafio sem acreditar na volta do marido, e temos apenas a feliz coincidência? Duas falas de Odisseu no Canto IX, uma antes e a outra depois da proposta, parecem apontar para a possibilidade de a esposa acreditar no seu retorno iminente e, portanto, agir com essa hipótese em mente: "Por isso te digo: ele

\footnotetext{
${ }^{32}$ Cf. Felson-Rubin, N. Regarding Penelope. From character to poetics. Princeton: Princeton University Press, 1994, p. 18 e 25.

${ }^{33}$ Cf. Murnaghan, op. cit., p. 133. U. Hölscher também chama atenção para o fato de que Odisseu não se deixa abalar pelas decisões da mulher porque, estando já presente, sabe que poderá impedir esse desfecho; cf. op. cit., p. 136.
} 
está são e salvo, e aqui/ aportará brevemente; não será por muito mais tempo/ que ficará longe da pátria. (...) Neste tempo chegará aqui Odisseu,/ entre a lua minguante e a lua nova" (XIX, 300-307); ${ }^{34}$ e "Pois o astucioso Odisseu virá antes que/ esses homens tenham armado o arco polido/ e feito passar a seta pelo meio do ferro" (XIX, 585-587).

Diante dessas falas - ambas a "enquadrar" a proposta do desafio poderíamos ser levados a ver uma cumplicidade latente entre marido e mulher. A favor dessa leitura, temos três elementos. Em primeiro lugar, há a confiança e tranquilidade de Odisseu, que, pelo que Homero nos mostra, em momento algum se sente ameaçado ou mesmo desconfia das reais intenções da mulher. Como diz Marylin Katz, "Penélope parece consolidar seus planos de um novo casamento e (...) Odisseu interpreta suas intenções da perspectiva dele (...). Odisseu nos garante, com a autoridade daquele cujos interesses são os que mais correm risco, que 'não é isso que Penélope quer dizer'". ${ }^{35}$

Em outras palavras, Odisseu, ao agir assim, reafirma a sintonia com a esposa, sintonia que, levada ao extremo, pode ser tomada como um reconhecimento mútuo e tácito: da parte dele, em relação à fidelidade dela; da parte dela, em relação à identidade dele. Nesse sentido, as indicações temporais fornecidas por Odisseu podem ser tomadas, por ambos, como uma referência velada ao dia seguinte, quando a matança acontecerá. ${ }^{36}$

O segundo elemento diz respeito à participação de Penélope no Canto XXI: ao fazer a proposta do desafio diretamente aos pretendentes (68-79), sabemos não só que a decisão, agora, foi impulsionada por Atena (1-4) - o que faz com que a astúcia fique sublinhada -, mas também que a própria Penélope intervém diretamente (dirigindo-se primeiro a

\footnotetext{
${ }^{34}$ Cf. XIX, 303-307 = XIV, 158-162.
}

${ }^{35}$ Cf. Katz, op. cit., p. 118.

${ }^{36} \mathrm{O}$ sentido de lukábas, no entanto, não é claro no verso 306, que traduzo por "neste tempo chegará aqui Odisseu"; alguns entendem como "mês, "ano" ou mesmo "dia". Cf. o que dizem Di Benedetto, V. Omero: “Odissea”. Milano: Rizzoli, 2010, p. 990; Jones, P. Homer's “Odyssey”. A commentary based on the translation of Richmond Lattimore. London: Bristol Classics Press, 1988, p. 132; Stanford, W. The "Odyssey” of Homer. London: St. Martin Press, 1947. Vol. II, p. 222-223; Monro, D. Homer's “Odyssey”. Vol. 2 (books XIII-XXIV). Oxford: Clarendon Press, 1901, p. 27; J. Russo, in: Heubeck, A. et alii (Org.). A commentary on Homer's "Odyssey". Vol. III (books 17-24). Oxford: Clarendon Press, 1992, p. 91-92; e Austin, op. cit., p. 244-247. É importante destacar, seguindo Austin, a celebração, no dia seguinte, da festa de Apolo "Numênio", ou da Lua Nova (XX, 149-156 e 276-278). 
Antínoo e depois a Eurímaco) para que seja dado ao mendigo participar da prova. As ironias em relação a ele "fazer dela sua mulher", ser "alto e bem constituído" e "de nobre linhagem" não passam despercebidas (312-319 e 331-342).

O terceiro e último elemento é ainda mais contundente. Tratase da percepção que o pretendente Anfimedonte tem, já no Hades, de que a prova do arco foi resultado de uma ação conjunta de marido e mulher (XXIV, 167-169). Se é verdade que essa afirmação equivocada serve para reforçar a ignorância destes jovens soberbos, não é menos verdade que ela serve também para reavivar, em nós, a suspeita de um entendimento "subterrâneo" entre Penélope e Odisseu, que Homero não explicita, mas apenas insinua. Ou seja: temos aí um ponto de vista - de "dentro" da narrativa - que reforça uma percepção externa ambígua: sabemos que Odisseu não agiu junto com a mulher (pelo contrário: ele fez questão de não se mostrar a ela antes da matança), mas não ficamos absolutamente certos de que Penélope não tomou a decisão que tomou agindo em resposta à presença do marido no palácio.

Não é possível abordar, aqui, o reconhecimento do Canto XXIII, que alongaria demais este artigo. Mas o comentário do episódio não destoaria, em linhas gerais, do resto da narrativa, vindo apenas confirmar a dubiedade de Penélope. Assim como acontece com a Capitu de Dom Casmurro, a suspeição e a duplicidade são sua marca. Se no caso do personagem de Machado de Assis ficamos nos perguntando se ela traiu ou não traiu Bentinho, se seu filho era ou não de Escobar, no caso de Penélope a traição está descartada, mas ainda assim nos perguntamos: ela reconheceu ou não Odisseu por detrás do disfarce? Agiu dissimuladamente? Estava disposta a se casar novamente? Sua colaboração com o marido foi voluntária ou casual? Se em Machado o efeito da dúvida é produzido pelo narrador não-confiável em primeira pessoa, em Homero o sentimento que Penélope desperta em nós advém, em grande parte, de uma narrativa silente e elíptica em relação a ela, e da exploração magistral das ironias. Como diz P. Harsh, Homero na Odisseia "dá grande peso ao implícito e ao sutil"37 - e a personagem de Penélope talvez seja o exemplo máximo da profunda caracterização que pode resultar dessa ferramenta.

${ }^{37}$ Cf. Harsh, op. cit., p. 2. 


\section{Referências}

AUSTIN, N. Archery at the dark of the moon. Poetic problems in Homer's "Odyssey”. Berkeley: University of California Press, 1975.

BYRE, C. Penelope and the suitors before Odysseus: "Odyssey" 18.158-303. The American journal of philology. Baltimore, vol. CIX, n. 2, p. 159-173, 1988.

CLAY, J. Homeric "akhreîon”. The American journal of philology. Baltimore, vol. CV, n. 1, p. 73-76, 1984.

COMBELLACK, F. Three Odyssean problems. California studies in classical antiquity . California, vol. VI, p. 17-46, 1973.

de JONG, I. A Narratological commentary on the "Odyssey". Cambridge: Cambridge University Press, 2001.

DI BENEDETTO, V. Omero: “Odissea”. Milano: Rizzoli, 2010.

FELSON-RUBIN, N. Regarding Penelope. From character to poetics. Princeton: Princeton University Press, 1994.

HARSH, P. Penelope and Odysseus in “Odyssey” XIX. The American journal of philology. Baltimore, vol. LXXI, p. 1-21, 1950.

HEUBECK, A. et alii (Org.). A commentary on Homer's “Odyssey”. Vol. III (books 17-24). Oxford: Clarendon Press, 1992.

HÖLSCHER, U. Penelope and the suitors (translated by Simon Richter). In: SCHEIN, S. (Org.). Reading the "Odyssey". Selected interpretive essays. Princeton: Princeton University Press, 1996.

JONES, P. Homer's “Odyssey”. A commentary based on the translation of Richmond Lattimore. London: Bristol Classics Press, 1988.

KATZ, M. Penelope's renown. Meaning and indeterminacy in the "Odyssey". Princeton: Princeton University Press, 1991.

LACEY, W. Homeric "hédna” and Penelope’s "kúrios”. The journal of Hellenic studies. London, vol. LXXXVI, p. 55-68, 1966.

LEVINE, D. Penelope's laugh: “Odyssey” 18.163. The American journal of philology. Baltimore, vol. CIV, n. 2, p. 172-178, 1983.

. Odysseus' smiles: “Odyssey” 20, 301, 22, 371 e 23, 111. Transactions of the American philological association. Baltimore, vol. CXIV, p. 1-9, 1984.

LOURENÇO, F. Homero: “Odisseia”. Lisboa: Cotovia, 2003.

MARQUARDT, P. Penelope “polytropos”. The American journal of philology. Baltimore, vol. CVI, p. 32-48, 1985.

MONRO, D. Homer's “Odyssey”. Vol. 2 (books XIII-XXIV). Oxford: Clarendon Press, 1901.

MURNAGHAN, S. Disguise and recognition in the "Odyssey". Princeton: Princeton University Press, 1987. 
NICKEL, R. Athene, Penelope and the vengeance plot against the suitors. Quaderni Urbinati di cultura classica. Urbino, vol.XCVI, n. 3, p. 29-54, 2010.

PRATT, L. "Odyssey" 19.535-550: on the interpretation of dreams and signs in Homer. Classical philology. Chicago, vol. LXXXIX, n. 2, p. 147-152, 1994.

ROZOKOKI, A. Penelope's dream in book 19 of the "Odyssey". The classical quarterly. Watford, vol. LI, n. 1, p. 1-6, 2001.

RUSSO, J. Interview and aftermath: dream, fantasy, and intuition in "Odyssey" 19 e 20. The American journal of philology. Baltimore, vol. CIII, n. 1, p. 4-18, 1982.

SAIID, S. Homer and the "Odyssey". Translated by Ruth Webb. Oxford: Oxford University Press, 2011.

STANFORD, W.Ambiguity in Greek literature. Oxford: Basil Blackwell, 1939. . The "Odyssey" of Homer. London: St. Martin Press, 1947.

STEWART, D. The disguised guest. Rank, role, and identity in the "Odyssey". Cranbury: Associated University Press, 1976. 